\title{
KLAIM KEBENARAN TEOLOGI DAN TUNTUTAN ZAMAN: Refleksi Kritis atas Etika Beragama
}

\author{
Naupal \\ Universitas Indonesia \\ pascafilsafat.ui.2014@gamil.com
}

\begin{abstract}
Abstrak
Artikel ini mendiskusikan klaim kebenaran teologi dan pengaruhnya sejak era pra-modern hingga post-modern. Klaim kebenaran teologi era pra modern, yang dipusatkan pada lembaga keagamaan dengan dimensi spiritualitas rendah yang menyebabkan terjadinya dehumanisasi, akibat dari kekuatan materialisme dalam sains dan kekosongan nilai moral. Bahaya terbesar dari kekosongan nilai moral adalah kemunculan persaingan abadi sebagai etika satu-satunya dalam hubungan antar manusia. Berangkat dari pengalaman masa lalu, saat ini teologi tidak dapat dipisahkan dari dimensi spiritual yang mendorong nilai-nilai toleransi dengan landasan kedudukan semua yang ada adalah manifestasi kasih sayang, kekuatan dan perasaan yang dimiliki Tuhan.
\end{abstract}

\section{Abstact}

THE THEOLOGICAL TRUTH CLAIMS AND THE FUTURE DEMANDS: CRITICAL REFLECTION TOWARD RELIGIOUS ETHICS. This article discusses the truth claims of theology and its influence on human civilization from the pre-modern to post-modern era. In fact, theological truth claims in pre-modern era that focused on religious institutions with a low spiritual dimension has resulted in the dehumanization, materialism in science, and void of moral values. The greatest danger of the void of moral values is the emergence of the eternal competition in human relations as a sole ethics. Departing from the past experience, the theology of the future should incorporate the spiritual dimensions of all existing position with the values of tolerance, which is a manifestation of God's power and love.

Kata Kunci: Kebenaran Teologi; Era Pra Modern; Dimensi Spiritual; Toleransi 


\section{A. Pendahuluan}

Tradisi pemikiran Barat dalam proses mencari kebenaran diawali oleh bangsa Yunani. Filsafat Yunani klasik berusaha mendobrak keagamaan tradisional bersama dewa-dewanya dengan bertanya tentang arkhe yang mendasari alam semesta. ${ }^{1}$ Sejalan dengan perkembangan pemikiran manusia, terjadi pergeseran obyek pemikiran tentang kebenaran, dari alam semesta menuju manusia itu sendiri. Selanjutnya manusia mulai berpikir dan mengakui ada substansi lain yang melampaui dirinya. Sosok tiga agama Abrahamik: Yahudi, Kristen, dan Islam pada mulanya menolak filsafat. Kitab suci mereka hampir kosong dari spekulasi filosofis. Sikap yang dituntut adalah bahwa kalau Tuhan berbicara, manusia tidak boleh mempertanyakannya melainkan mendengarkan-Nya. Dalam Islam tradisi seperti ini terlihat jelas misalnya dalam pandangan Imam Maliki yang menjawab pertanyaan orang tentang arti istiwā, yang terdapat dalam firman Allah, ar-Rahmān 'ala al-'arsyi istawā, dengan mengatakan, istiwā itu diketahui, hal ihwalnya tidak diketahui, beriman tentangnya wajib dan mempertanyakan itu bid'ah. ${ }^{2}$ Tetapi abstinensi dari filsafat tidak tahan lama. Manusia tidak hanya ingin taat pada Tuhan, tetapi juga ingin mengerti apa yang ditaatinya. ${ }^{3}$ Pada tahap ini filsafat dibutuhkan sebagai kendaraan klaim kebenarannya. Klaim kebenaran agama menjadi sebuah permasalahan serius lewat doktrinnya mengenai keselamatan yang ditandai dengan munculnya institusi agama.

Sebagai ultimate concern (tujuan akhir) dan hal terpenting dalam kehidupan manusia, agama memainkan peran yang cukup besar dalam setiap kehidupan manusia di alam ini dan akhirnya

${ }^{1}$ Pandangan ini disebut monisme yang memandang alam merupakan keseluruhan yang bersatu tanpa ada ketegangan, sesuatu yang harmoni. Pandangan ini didukung oleh Thales, Anaximenes, Anaximandros, Phytagoras, Heraklitos. Lihat Frederick Copleston: A History of Philosophy, volume I, Greek and Rome (New York : Double Day,1993), h. 24.

${ }^{2}$ Syahrastani, Kitab al-Milāl wa an-Nihal, ed Muhammad ibn Fathullah Badran ( Kairo: tt), h. 85.

${ }^{3}$ Pada abad pertengahan, filsafat Aristoteles diterima sebagai kerangka filsafat utama untuk memahami problem-problem teologis. Dengan filsafat Aristoteles memungkinkan kaum intelektual Barat untuk membedakan antara pendekatan teologis dan pendekatan filosofis. Lihat Frans Magnis Suseno, Menalar Tuhan, (Yogyakarta: Kanisius, 2006), h. 45-46. 
membentuk suatu pandangan dunia (world view). Orang Yahudi, Kristen, Islam yang taat ingin selalu berada dalam keselarasan dengan Tuhan yang abadi, dengan menaati aturan-Nya yang diwahyukan secara pasti melalui Moses, atau melalui Yesus dari Nazaret, atau melalui Muhammad dari Mekkah. Penganut kitab Weda ingin berada dalam keselarasan, atau menyadari kesatuannya dengan Brahman yang abadi. Seorang penganut Taoisme ingin hidupnya selaras dengan Tao yang abadi.

Tulisan ini berusaha menjelaskan sejarah klaim kebenaran teologi dengan karakteristiknya masing-masing, semenjak abad pertengahan sampai dengan abad postmodern ini. Di sisi lain dunia kita sekarang ini juga ditandai dengan munculnya kelompok garis keras, fundamentalisme, radikalisme agama yang bersifat destruktif yang tak kalah kejamnya dengan abad pertengahan. Fenomenafenomena tersebut mengharuskan kita merekonstruksi peran teologi dengan klaim kebenarannya yang sifatnya humanis, inklusif, dan toleran. Dalam konteks Indonesia, dibutuhkan penafsiran ulang terhadap makna dan peran teologi yang tidak lagi berlindung dalam jubah ke-llahian dan akhirnya mereduksi dimensi kemanusiaan, padahal tujuan dari teologi itu sendiri adalah memerdekakan manusia dari segala bentuk penghambaan selain kepada Tuhan, sehingga akhirnya manusia semakin menjadi otonom dan humanis.

\section{B. Pengertian Teologi}

Tuhan sebagai objek kajian metafisika memiliki kekhususan dibanding obyek metafisika lainnya. Manifestasi lahiriah dari semesta maupun jiwa dapat ditangkap indera, maka hal yang sama tidak berlaku bagi realitas ketuhanan. Tuhan adalah sesuatu yang mutlak yang tidak dapat ditangkap oleh indera. Pandangan yang mengatakan bahwa kita hanya dapat mengenal Tuhan lewat penyingkapan dari diri-Nya sendiri yakni lewat wahyu disebut dengan teologi wahyu, sedangkan teologi natural adalah pandangan yang mengatakan bahwa kita dapat mengenal Tuhan tanpa lewat wahyu, tetapi lewat nalar akal budi yang bersifat apriori, atau lewat pengamatan atas fenomena-fenomena alam yang bersifat aposteriori. 
Apabila teologi natural mengambil Tuhan sebagai titik akhir atau kesimpulan dari seluruh pengkajiannya, maka teologi wahyu memandang Tuhan sebagai titik awal pembahasannya. ${ }^{4}$ Sebenarnya tidak ada kesepakatan di antara para ahli tentang istilah teologi dan jenis-jenisnya. Di satu pihak ada yang mengatakan bahwa teologi benar-benar berbeda dengan filsafat, tetapi ada yang memasukkan teologi ke dalam filsafat. Paul Edwards, editor dari EncyclopedIa of Philosophy memasukkan teologi ke dalam sejarah filsafat agama dan problematika filsafat agama.

Sementara Virgilius Vern mengatakan bahwa, teologi berasal dari bahasa Yunani theos yang berarti Tuhan, dan logos yang berarti ilmu. Dalam arti sederhana teologi berarti studi masalahmasalah Tuhan dan kaitan Tuhan dengan dunia realitas. Jadi, dalam pengertiannya lebih luas teologi merupakan cabang filsafat, yaitu cabang filsafat yang merupakan lapangan khusus atau bidang penelitian filsafat yang khusus berkenaan dengan masalah Tuhan yang dipergunakan dalam arti theoretical expression of a particular religion, ekspresi teoritis tentang suatu agama tertentu. Dalam arti ini, teologi merupakan fase-fase diskusi teoritis tentang kepercayaan agama tertentu yang bersifat historik, sistematik, polemik, apologetik, dan sebagainya. Dalam arti ini juga teologi merupakan diskusi teoritis murni tentang Tuhan dan hubungannya dengan dunia atas dasar penelitian yang bebas.

S.G.FBrandonmengungkapkan bahwa teologisebagaidiscource about God, sebagai pembicaraan atau diskusi yang mempersoalkan tentang Tuhan, yang kemudian dalam arti luas diterjemahkan sebagai studi sistematis dan ilmiah terhadap suatu agama. Dalam dunia Kristen sendiri dikenal berbagai jenis teologi, seperti teologi dogmatik, teologi biblikal, teologi moral, teologi asketikal, mistical, symbolic, sacramental, apological, pastoral, philosophical, liturgical, dan teologi natural. ${ }^{5}$

Definisi-definisi di atas merupakan definisi teologi pada masa abad pertengahan sampai dengan masa modern. Definisi teologi

${ }^{4}$ Lihat David Stewart, Exploring the Philosophy of Religion, (Englewood Cliffs, N.J: . Prentice-Hall, 1980), h. 64-67.

${ }^{5}$ S.G.E Brandon, "Theology" dalam S.G.E Brandon, M.A, DD., (ed.) A Dictionary of Comparative Religion, (New York: Charles Scribner's Sons, 1970), h. 610. 
seperti yang dimaksud di atas, dikritik oleh Hassan Hanafi sebagai terlalu melangit dan jauh dari dimensi kemanusiaan yang akhirnya malah bermuara pada teologi yang melembaga, dan akhirnya melahirkan berbagai firqah dan mazhab yang menimbulkan konflik dan perseteruan yang tidak sekedar memunculkan bentuk pemikiran tetapi juga korban nyawa, baik di dunia Islam maupun Barat. Ia mengusung teologi dalam pengertiannya yang baru, yang secara metaforis-analogis harus berujung pada rekonstruksi peran Islam sebagai agama prophetic. ${ }^{6}$ Rekonstruksi ini mengarahkan sasarannya kepada kemanusiaan sebagai tujuan beragama. Dengan demikian watak keberagamaan ditafsirkan dalam tataran kemanusiaan, yang bukan ke-llahian, dan teologi tidak terkungkung dan mengatasnamakan kesucian Tuhan, yang secara alamiah menginformasikan tentang semangat revolusi kemanusiaan yang ditandai dengan gerakan pembaharuan yang potensinya menuju pada suatu kebangkitan.

Hal yang sama juga dikemukakan oleh Karel Steenbrink, seharusnya teologi membahas dua masalah besar, pertama tentang Tuhan; dan kedua tentang hubungan antara Tuhan dengan segala realitas termasuk manusia yang akan melahirkan nilai-nilai etis, karena lebih banyak berwujud hidup yang praktis. ${ }^{7}$

Dalam tulisan ini, teologi diartikan tidak hanya sebagai refleksi atas iman sebagai kebenaran atau sebagai pengalaman spiritual, tetapi teologi juga diartikan sebagai implementasi makna iman bagi pengembangan potensi kemanusiaan. Dalam arti ini baik teologi maupun iman tidak hanya berhenti pada berbicara hakikat Tuhan sebagai asal-usul semua pengada, tapi iman dan teologi adalah juga refleksi kritis atas praksis untuk transformasi dunia. Seorang teolog tugasnya tidak hanya membaca kembali sejarah dan kitab suci tetapi lebih dari itu adalah membuat kembali sejarah. Jadi, pertama, iman dimaknai sebagai sikap percaya secara

${ }^{6}$ Peran propethic dari agama adalah mengedepankan konsep anthropos (kemanusiaan), dan bukan theos (ketuhanan), manusialah yang nantinya menjadi fokus dan objek kajian yang berkiblat pada kebebasan, persamaan, dan keadilan. Lihat Hassan Hanafi, Mina al-Aqïidah ila as-Sawrah, (Kairo: Maktabah Madbouli, 1988), Vol. 1, h. 59-66.

${ }^{7}$ Karel A. Steenbrink, Perkembangan Teologi dalam Dunia Kristen Modern, (Yogyakarta: IAIN Sunan Kalijaga Press, 2005), h. 11. 
positif terhadap kebenaran-kebenaran yang diyakini dalam konteks keagamaan sebagai bagian dari pewahyuan Ilahi yang termuat dalam wahyu llahi; kedua iman menunjuk pada pengembangan potensi kemanusiaan sesorang dalam hubunganya dengan sesama makhluk Tuhan.

\section{Klaim Kebenaran Teologi Pra Modern dan Tanggapan Atasnya}

Pada masa pra modern, metafisika mendapat muatan teologi adikodrati. Adalah Agustinus (354-430 M) yang mengajarkan bahwa kebenaran iman mempunyai kedudukan dan nilai kesempurnaan yang lebih tinggi dari kebenaran rasional atau kodrati. Manusia dapat mengenal kebenaran Ilahi, tetapi hal itu hanya mungkin karena dikondisikan demikian oleh Sang Pencipta. Manusia mempunyai dua lapisan intelek, kebenaran Ilahi yang dapat ditangkap oleh ratio superior (rasio yang tinggi), sedangkan aplikasinya pada realitas material agar menghasilkan pengertian kodrati dilakukan oleh ratio imperior (rasio yang rendah). Pekerjaan ratio superior termasuk wilayah iman dan teologi, sedangkan ratio imperior merupakan instrumen utama dalam filsafat. ${ }^{8}$

Corak berpikir Agustinus dilanjutkan oleh St. Anselmus (1093-1109 M) dari Canterburry. Baginya fungsi filsafat hanyalah sekedar membantu untuk memberikan pengertian mengenai apa yang diimani, pada akhir bab pertama dari bukunya yang berjudul ProslogIan, ia mengemukakan tesisnya yang terkenal berbunyi: "Credo ut intellegam"(saya percaya supaya dapat mengerti, atau dalam ungkapan yang lebih popular "Fides Quarrens intellectum: (iman mencari pengertian). Menurut jalan pikiran ini, agar dapat mengenal Allah secara rasional dan mendalam seorang filsuf harus berangkat dari fakta pengalaman iman, dari sana dapat disusun konsep-konsep yang lebih abstrak.

Sebagaimana diketahui sebelumnya kaitan filsafat dan teologi begitu dekat, tapi situasi itu berubah dengan munculnya modernitas. Modernitas dicirikan sebagai era diesseitigkeit, yaitu era meninggalkan visi kudus (sakral) tentang eksistensi, kemudian

${ }^{8}$ Coplestone, A History of Philosophy, volume II. Medieval Philosophy, from Agustin To Dons Scotus, (New York: Doubeday, 1993), h. 68. 
afirmasi terhadap nilai-nilai yang profan (sekuler) sebagai gantinya. Skeptisisme teologis ditandai dengan berbagai argumen yang saling berkaitan, di antaranya adalah masalah kejahatan. Masalah ini jelas tergambarkan dalam pertentangan antara kebaikan dan kekuasaan Tuhan yang diyakini ada pada Tuhan, dan pengalaman tentang adanya kejahatan. Rumusan problem kejahatan yang cukup terkenal telah dirumuskan sejak zaman Yunani oleh Epikuros (342-270 SM) :

"Ataukah Allah berkehendak untuk menghapuskan kejahatan, dan Ia tidak dapat atau Ia dapat, dan Ia tidak mau; ataukah Ia tidak ingin dan tidak dapat; ataukah Ia mau dan dapat. Jika ia mau dan tidak dapat, Ia lemah, dan ini tidak sesuai dengan sifat Tuhan; jika Ia dapat dan, Ia jahat, dan ini juga tidak sesuai dengan sifat Tuhan, jika Ia tidak mau dan tidak dapat; Ia jahat dan lemah, sehingga Ia bukan Tuhan, jika Ia mau dan dapat ini sesuai dengan sifat Tuhan. Darimanakah sumber kejahatan? Atau mengapa Ia tidak meniadakannya?

Paham kejahatan sebagai privatio boni (tiadanya kebaikan dari yang seharusnya ada) sebagaimana yang digagas dalam metafisika Agustinus yang mengatakan bahwa kejahatan tidak pernah diciptakan oleh Tuhan, melainkan sebagai akibat dari penyalahgunaan kebebasan manusia tidak dapat diterapkan secara empiris, khususnya jika kita melihat adannya natural evil, misalnya gunung meletus, gempa bumi dan segala hal yang independen dari kebebasan manusia. Demikian juga jika diterapkan dalam kejahatan moral, misalnya dalam pembunuhan besar-besaran oleh NAZI, apakah kejahatan itu seperti hanya melulu tiadanya kebaikan? Padahal peristiwa itu sungguh-sungguh merupakan suatu tragedi yang benar-benar jahat.

Erat kaitannya dengan problem kejahatan adalah adanya pandangan kemahakuasaan Tuhan yang mengatakan bahwa dunia diciptakan secara ex nihilo. Ini berarti bahwa Tuhan tidak menciptakan dunia dari materi yang sudah ada, sehingga alam ini tidak memiliki energi sendiri. Dan karena dunia betul-betul diciptakan dari ketiadaan, dunia ini tidak memiliki energi maka segala yang terjadi didunia ini digerakkan oleh penggerak pertama, yakni Tuhan sebagai causa prima. Hal ini akan sulit dimengerti jika

${ }^{9}$ Dikutip dari Ahern, M.B., The Problem of Evil, (Routledge \& Kegan Paul: London, 1971), h. 2. 
dihubungkan dengan adanya problem kejahatan sementara Tuhan diyakini sebagai Maha Baik dan Maha Kuasa.

Dalam tradisi pemikiran modern, suatu pernyataan dikatakan bermakna atau tidak adalah dengan mengajukan pengujian atas suatu pernyataan lewat teori koherensi, korespondensi, yang kemudian diuji oleh pengamatan. Menurut pandangan ini, keyakinan dan pernyataan teologis tidak koresponden dengan kenyataan. Dalam pada itu para pemikir dan pendiri pandangan dunia modern, seperti Descartes, Newton, dan Boyle adalah bagian dari tradisi voluntaristik Agustinian yang jauh lebih menekankan kemahakuasaan Tuhan dibandingkan dengan teologi Thomas Aquinas yang menekankan partisipasi di samping dependensi Tuhan terhadap ciptaan-Nya. Para pemikir modern awal ini, yang mendefinisikan modernisme pada tahap pertamanya, secara eksplisit menolak pendapat yang menyatakan bahwa dunia memiliki energi yang inheren dalam dirinya. ${ }^{10}$ Penolakan tersebut semakin memperjelas pertentangan dogma kebaikan Ilahi dengan realitas kejahatan di dunia.

Paham kebebasan dan otonomi manusia juga dapat menjadi alasan untuk menolak eksistensi Tuhan. Anggapan bahwa percaya pada Tuhan dapat menghambat dorongan untuk mendapatkan kebebasan manusia dari segala bentukpenindasan secara menyeluruh terlihat jelas dalam benturan yang terjadi antara Galileo dan otoritas gereja dan sering disebut sebagai model bagi konflik antara ilmu pengetahuan dengan teologi. Keinginan untuk memiliki kebebasan intelektual sehingga semua masalah bisa diselesaikan melalui pengalaman inderawi (observasi ilmiah) dan penalaran berbenturan dengan pendekatan pada kebenaran yang diyakini tidak dapat salah karena datang dan berasal dari Tuhan.

\footnotetext{
${ }^{10}$ Menurut Boyle, tidak adanya kemampuan materi untuk bergerak sendiri membuktikan eksistensi Tuhan: "Karena materi tidak memiliki pergerakan . . . pergerakan semua benda paling tidak di awal segala sesuatu . . . diberikan kepada mereka,... Newton mengatakan bahwa karena materi harus digerakkan dari luar, kita menjadi percaya akan adanya "Penggerak kekal yang maha kuasa”, yang karena berada di segala tempat, . . . dengan kemauannya mampu menggerakkan bendabenda di dalam daerah kekuasaannya yang tidak terbatas. Untuk pembahasan tentang Newton dan Boyle tentang topic ini. Lihat Eugene Klareen, Religious Origins of Modern Science: Belief in Creation in Seventeenth-Century Thought, (Grand Rapids, Mich.: William B. Erdsman, 1977).
} 
Sejumlah kardinal sebenarnya menaruh simpati terhadap Galileo, tetapi Paus dan sekelompok kardinal yang berpengaruh secara politis menentangnya. Akhirnya Galileo dikutuk karena dianggap mempertanyakan literalisme (tafsiran harfiah) biblikal dan itu diartikan menentang gereja ${ }^{11}$ Pada tahun 1633, penguasa gereja menyatakan Galileo bersalah, karena mendukung teori Kopernikus bahwa bumi berputar mengelilingi matahari. Galielo dicerca dan ditempatkan di dalam sebuah rumah tahanan selama tujuh tahun sampai akhirnya ia digantung. Penguasa gereja sebenarnya sudah lama mengetahui bahwa esensi argumen Galileo benar dan bahwa doktrin gereja itu sendiri didasarkan atas asumsi yang salah. Namun demikian, gereja Katolik memerlukan waktu lebih dari tiga setengah abad untuk menyampaikan permohonan maaf secara resmi atas kasus Galileo. ${ }^{12}$

Dorongan untuk menentukan nasib sendiri secara sosial politik berbenturan dengan sistem sosial politik yang dinyatakan berasal dari Tuhan. Begitu tingginya peran teologi pada abad pertengahan di dunia Barat membuat filsafat menjadi hamba dari teologi, bahkan kemudian diikuti adanya legitimasi teologi bagi kekuasaan. Berubahnya teologi menjadi idiologis dalam sistem sosial politik terlihat jelas pada ayat-ayat dalam Surat Rasul Paulus kepada umat di Roma pasal 13 yang menyatakan bahwa Tuhanlah yang menobatkan para penguasa, digunakan untuk mendukung hak Ilahi raja-raja terhadap gerakan-gerakan demokratis. Secara umum status quo didukung oleh keyakinan tentang kebaikan dan keMaha Kuasaan Tuhan. Para pemikir abad modern, seperti Karl Marx mengkritik dan menuduh agama menjadi pembela status quo dalam sejarah. Tujuannya adalah menguasai rakyat dengan mewartakan kemutlakan nasibnya sebagai rakyat yang melarat, menderita dalam belenggu tokoh-tokoh politik dan agama. Agama selalu memihak kepada penguasa, bersikap konservatif, dan mempertahankan struktur sosial politik yang ada.

${ }^{11}$ Lihat Jerome J. Langford, Galileo, Science, and the Church, (Ann Arbour: University of Michigan Press, 1971).

${ }^{12}$ Permohonan maaf dilakukan pada bulan Oktober 1992 ketika Paus Paulus Yohanes II. Keterangan lebih lanjut lihat Charless Kimball, Kala Agama Menjadi Bencana, terjemahan Nurhadi, (Bandung : Mizan, 2003). 
Alasan lain yang menyebabkan hilangnya kepercayaan kepada Tuhan dalam lingkungan intelektual modern adalah pandangan sains modern yang bersifat deterministik-reduksionis dan realistikmaterialis. Pandangan Newtonian bersifat deterministik, yakni masa depan suatu sistem, pada prinsipnya dapat diprediksi dari pengetahuan yang akurat tentang kondisi sistem itu sekarang. Ia bersifat reduksionistik, yaitu perilaku sistem ditentukan sepenuhnya oleh perilaku bagian-bagian terkecilnya, dan ia bersifat realistik-materialis, yakni teori ilmiah dapat menggambarkan dunia sebagaimana adanya tanpa dipengaruhi pengamat. Tiga asumsi dasar ini sebenarnya digugat dalam fisika kuantum abad ke 20 .

Gambaran alam yang seperti itu menciptakan kesadaran apa yang disebut oleh Bermen sebagai disenchantment of the world (hilangnya keterpesonaan alam raya), dan kesadaran reduksionis ini disebut oleh Bermen sebagai non participant consciousness. ${ }^{13}$ Setelah semua ilmu alam menggunakan paradigma materialistikdeterministik-reduksionis dan mekanistik, maka ilmu-ilmu sosial kemanusiaan pun, seperti sosiologi dan psikologi ikut terpengaruh oleh paradigma zeitgeist peradaban modern itu.

Di sisi lain dimensi spiritualitas dan religiositas dari agama pada abad pertengahan di dunia Barat kurang mendapatkan tempat. Bukti-bukti bagi keringnya dimensi spiritual dalam teologi abad pertengahan misalnya dapat dilihat dari beberapa aspek teologi Agustinus, di antaranya adalah masalah yang berhubungan dengan kontroversi Donatis.

Kontroversi Donatis intinya adalah adanya pertanyaan apakah bila seorang pastor kurang memiliki kebajikan akan berpengaruh pada sakramen yang diberikannya. Kaum Donatis mengatakan, "Ya". Sakramen yang diberikan melalui pastor yang jahat tidak akan bisa membawa ke keselamatan. Agustinus mengatakan, "Tidak". Kemujaraban suatu sakramen yang diberikan oleh Tuhan melalui Yesus tidak bergantung pada kualitas subyek moral dan spiritual pastor yang memberikannya. Secara teologis pendiriannya berakar pada ke-Maha Kuasaan Tuhan.

${ }^{13}$ Lihat Bermen, M., The Reenchanment of the World, (New York: Bantam Books, 1984), h. 57-125. 
Menurut Agustinus, bila dikatakan bahwa kurangnya kebajikan pada seorang pastor bisa menghalangi efektivitas rahmat Tuhan yang datang melalui sakramen akan berarti bahwa kaum bidaah mempunyai kekuatan untuk mengotori segala sesuatu milik Tuhan, yaitu bahwa kekuatan manusia bisa menyelewengkan maksud Tuhan yang sebenarnya. Secara khusus Agustinus menentang usaha kaum Donatis untuk menunjukkan bahwa karakter manusia yang dipermandikan akan mengikuti orang yang mempermandikannya. Pandangan Agustinus inilah yang dalam perkembangannya menjadi ortodoksi.

Meskipun Agustinus hanya membahas pengantaraan rahmat melalui sakramen, bukan pada karakter seorang pastor, namun secara umum berpengaruh pada kehidupan umatnya, sikap anti donatis gereja berpengaruh pada anggapan semakin kurang pentingnya keunggulan spiritual para pendeta Kristen. Pesan umum pendirian ini yaitu bahwa Tuhan itu maha kuasa. Kemujaraban rahmat Tuhan tidak bergantung pada kualitas manusia sebagai alat yang mengantarainya. Oleh sebab itu pendeta atau pastor itu tidak perlu menyucikan dirinya untuk menjalankan tugas pokoknya. Cara resmi untuk mengkomunikasikan rahmat Tuhan ini bekerja secara ex opera operato.

Singkatnya teologi tersisih karena pandangan dunia modern yang tidak memberi tempat lagi baginya. Dampak dari semakin tersisihnya teologi dari ruang publik adalah munculnya gerakan fundamentalisme. ${ }^{14}$ Fenomena fundamentalisme dalam tradisi keagamaan dunia, ekspresinya terkadang sangat mengerikan, karena seringkali menggunakan instrumen kekerasan. Kaum fundamentalis, menurut Amstrong, cenderung memberlakukan penafsiran harfiah terhadap kitab-kitab suci mereka serta menerima doktrin-doktrin inti tertentu secara tertutup..$^{15}$ Mereka dibutakan oleh visi religius yang ganas, yang mengunci mereka dalam sebuah prasangka ekslusif lama. Pandangan seperti ini tentu saja sangat

${ }^{14}$ Fundamentalisme mengambil bentuk dan wajah keberagamaan yang keras dan kaku dalam menghadapi realitas kemajuan modern serta kelompok lain di luar kepercayaan mereka. Kelompok ini biasanya memahami teks suci secara literal/ harfiah. Karena itu kelompok ini sering disebut dengan kelompok skriptualistik.

${ }^{15}$ Lihat Karen Amstrong, The Battle for God, (New York: Alfred A. Knofi, 2001), h. 29-30. 
tidak kondusif dan bahkan berbahaya dalam kondisi masyarakat yang semakin majemuk dewasa ini, yang menuntut keterbukaan, dialog, dan saling menghormati di antara sesama umat manusia.

Dalam sejarah perkembangan Islam, persekutuan antara teologi dengan politik ini tampak dari awal munculnya ilmu kalam atau teologi. Aliran pemikiran yang muncul misalnya, aliran Khawarij, Syiah, dan Murjiah, mempunyai latar belakang politik. Aliran khawarij adalah respon yang mewakili perlawanan suku Badui menentang hegemoni kekuasaan suku Quraisy. Aliran Syiah mewakili dukungan Ali dalam kursi kekhalifahan; dan aliran Murjiah mewakili kepentingan dinasti yang ingin berkuasa, khususnya dinasti Ummayah di lingkungan Suku Quraisy.

Dalam kasus di Indonesia, kehadiran kelompokkelompok fundamentalis, baik dalam bentuk organisasi massa, seperti HTI (Hizbu Tahrir Indonesia), FPI (Front Pembela Islam), atau dalam bentuk lembaga Pendidikan, seperti Pesantren alMukmin, Pesantren al-Islam, dan Jama'ah Salafiah telah membentuk image baru terhadap agama Islam, sebagai agama yang tidak toleran, anti demokrasi, dan cenderung kepada kekerasan dan teror. Seiring waktu berjalan dan karena adanya motivasi ideologi kepentingan kelompok, makna jihad dipahami secara literal dan dangkal, sebagai perang melawan orang-orang kafir di manapun mereka dijumpai. Contoh kasus yang paling fenomenal adalah seorang teroris bernama Amrozi, yang sambil mengelus-elus jenggotnya tersenyum manis menunjukkan ekspresi wajah tanpa dosa, ketika ia di sidang dalam tragedi bom Legian-Bali, yang telah menewaskan sekitar 200 orang. Amrozi dikenal sebagai the smiling suspect, sehingga membuat jengkel keluarga-keluarga korban. Yang ia bayangkan adalah surga yang dijanjikan Tuhan sebagai imbalan 'memberantas kemaksiatan' itu. Keyakinan bahwa apa yang ia lakukan merupakan jihad.

Gerakan fundamentalisme jelas bersifat destruktif dan tidak membangun ke arah peradaban dunia yang toleran dan menghidupkannya berarti menghidupkan gerakan keagamaan klasik yang salah. Teologi yang menjadi idiologis dan agamaagama yang melembaga secara formal dan terorganisasi (organized religion) seperti kata Fromm, seharusnya tidak lagi dihargai karena dianggap terlalu otoriter terhadap manusia konkrit. Kecenderungan 
otoritarian menurut Fromm berakar pada karakter sosial yang menjadi dasar dari desktruksi dalam kehidupan manusia. Agama yang berkecenderungan otoritarian oleh penganutnya yang berkarakter sosial otoritarian yang dapat menyumbangkan situasi dehumanisasi. ${ }^{16}$

Dalam sejarah Barat, konflik antara teologi dan politik dan konflik antara teologi dengan sains akhirnya berujung dengan munculnya modernitas. Modernitas yang ditandai dengan desakralisasi terhadap pengetahuan yang bersifat ketuhanan, dan menafikan intuisi yang menjadi sarana mengantarkan manusia kepada Tuhan dan selanjutnya berakibat pada pengosongan alam dari keberadaan Tuhan. The desecularization of the cosmos was related to the secularization of reason, atau sebaliknya the desacralization of knowledge was related directly to the desacralization of the cosmos. ${ }^{17}$ Dengan kalimat yang lebih populer, masyarakat Barat modern memasuki the post-Christian Era dan memasuki masa sekularisasi dalam berbagai kehidupan. Sekularisasi di sini yang pada awalnya diterapkan dengan cara memisahkan antara institusi gereja yang mengurusi agama, dan institusi negara yang mengurusi masalah politik, dalam perkembangan selanjutnya memasuki wilayah alam pikiran manusia berupa sekuralisasi kesadaran. Sebagaimana yang ditegaskan oleh C.A Van Peursen, yakni terbebaskannya manusia dari kontrol ataupun komitmen terhadap nilai-nilai agama, dan kemudian dari metafisika atas aktivitas sehari-hari, yaitu alam pikirannya dan bahasanya. ${ }^{18}$

Ketika modernitas sudah mendapat ruang keselamatan lain di luar teologi, dan keselamatan dianggap bisa diperoleh melalui kemajuan materi, teknologi, dan ilmu pengetahuan, maka agama dianggap tidak relevan dan tidak penting, kemudian teologi direduksi dalam ruang privat yang tidak punya makna dan pengaruh bagi kehidupan sosial, maka masyarakat modern Barat telah kehilangan

${ }^{16}$ Penggambaran tentang agama otoritarian dan agama humanistik dapat dilihat dalam buku Erich Fromm, Religion and Psychoanalysis, (New York: Vail-Ballou Press, Ins., 1997), h. 19-64.

${ }^{17}$ Sayyed Hussein Nasr, Knowledge and the Sacred, (New York: State University of New York Press, 1989), h. 45.

${ }^{18}$ Dikutip oleh Komaruddin Hidayat, Tragedi Raja Midas: Moralitas Agama dan Krisis Modernisme, (Jakarta, Paramadina, 1988), h. 265. 
visi kellahian, yang telah tumpul penglihatan intellectusnya ${ }^{19}$ dalam melihat realitas kehidupan.

Dualisme jiwa dan tubuh, spiritual dan material, yang awalnya digagas oleh Descartes di awal modernisme akhirnya berujung pada materialisme, tanpa jiwa dan tanpa dimensi spiritual. Atau kalaupun dimensi jiwa dan spiritual dianggap masih ada, maka itu dianggap sebagai keyakinan pribadi dan masuk dalam wilayah privat.

Paradigma dualisme Cartessian-Newtonian kemudian memperlakukan manusia dan sistem sosial seperti mesin besar yang diatur menurut hukum-hukum obyektif, mekanistik, deterministik, linier, dan materialistik. Cara pandang ini memandang alam sebagai sesuatu yang mati (lifeless nature) yang oleh Alfred North Whitehead disebut sebagai pola pikir scientific materialism. ${ }^{20}$ Pola pikir ini menempatkan materi sebagai dasar dari semua bentuk eksistensi, dan menganggap alam kosmos sebagai suatu kumpulan objek-objek yang terpisah yang dirakit menjadi sebuah mesin raksasa.

Jurgen Habermas (1929) juga menolak filsafat kesadaran Descartes dan menyebutnya sebagai rasionalitas instrumental, yakni rasionalitas yang bekerja berdasarkan tujuan yang telah ditetapkan oleh subyek yang berpikir. Dengan cara ini subyek yang berpikir akan menganggap berbagai hal di luar pikirannya sebagai obyek pasif yang menunggu dikerjakan. Bagi Habermas, filsafat model ini hanya menghasilkan obyektivisme dan positivisme dan pada gilirannya menghasilkan dehumanisasi dan kerusakan lingkungan. ${ }^{21}$

Konsekwensi yang harus dibayar dari pandangan dunia yang materialistik adalah tidak diakuinya realitas transenden, yang disebut Tuhan oleh umat beragama. Konsekwensi lebih lanjut adalah munculnya relativisme segala norma dan nilai. Padahal gagasan dasariah tentang Tuhan adalah gagasan tentang adanya

${ }^{19}$ Istilah intellectus memiliki konotasi kapasitas mata hati, satu-satunya elemen pada diri manusia yang sanggup menangkap bayang-bayang Tuhan yang diisyaratkan oleh alam semesta.

${ }^{20}$ Alfred North Whitehead, Science and the Modern World, (New York: Mentor Book, 1954), h. 18.

${ }^{21}$ Lihat Jurgen Habermas, The Philosophical Discourse of Modernity, (Massachussetts: The MIT Press Cambridge, 1992), h. 294-326. 
suatu pribadi universal dan bertujuan, yang tujuan universalnya dijadikan standar tolok ukur keinginan dan tujuan mahluk-makhluk yang fana. Kehendak Ilahi memberikan tempat pada segala norma dan nilai yang obyektif bagi kesadaran manusia. Kematian Tuhan seperti yang ditekankan oleh Nietzsche berarti hilangnya norma transenden itu. ${ }^{22}$

Konsekwensi berikutnya adalah nihilisme, menurut pandangan ini bagaimana kita menjalani hidup, termasuk bagaimana kita memperlakukan orang lain akhirnya tidak penting. Manusia yang memiliki pandangan seperti ini menghasilkan dunia yang sangat berbahaya, seperti dehumanisasi, eksploitasi manusia atas manusia lain, dan puncaknya diterimanya Darwinisme sosial, yang mengatakan bahwa survival for the fittest sebagai satu-satunya etika.

Berdasarkan gambaran di atas, maka perlu dilakukan pendefinisikan ulang tentang Tuhan yang lebih sesuai dengan keadaan. Penyelematan Tuhan dengan cara pendefinisian ulang berarti menolak gagasan Tuhan kaum konservatif tradisional dan Tuhan kaum liberal modern. ${ }^{23}$ Perlunya pemahaman dan perubahan paradigma dalam melihat hubungan Tuhan dan alam yang menjadi code of conduct manusia dalam berhubungan dengan sesama dan dengan alam sekitar.

Ada juga teolog modern yang berusaha mendapatkan gagasan teologi tradisional tentang Tuhan dengan pandangan dunia modern dengan membuat keduanya menjadi saling independensi. Strategi itu menyatakan bahwa, ilmu pengetahuan dan agama adalah dua bidang kajian yang sama-sama otonom, sehingga tidak ada konflik di antara keduanya.

${ }^{22}$ Lihat Franklin L. Baumer, Religion and the Rise of Scepticism, (New York: Harcout, Brace \& World, 1980).

${ }^{23}$ Menurut David Ray Griffin, teologi konservatif-fundamentalisformalistik dicirikan lewat pemahamannya terhadap wahyu secara literal, dan utuh; sementara teologi liberal modern melihat wahyu lebih sebagai ajaran moral, sehingga berusaha menghindari konflik dengan ilmu pengetahuan; dan jenis yang ketiga adalah teologi naturalistik postmodern yang posisinya menawarkan untuk mengatasi pertentangan pandangan religius liberal dan pandangan konservatif fundamentalis. Lihat David Ray Griffin, Tuhan dan Agama dalam Postmodern, terj. Gunawan Admiranto, (Yogyakarta: Kanisius, 2005), h. 15. 
Tokoh utama yang pertama menggunakan pendekatan ini adalah Immanuel Kant. Ia membedakan dua fungsi pikiran manusia yang berbeda secara mendasar, yaitu yang ilmiah (teoritis), dan yang etis (praktis). Saat berfungsi secara ilmiah, pikiran manusia melihat dunia sebagai tidak ada kebebasan dan tidak ada nilai spiritual; saat berfungsi secara praktis, pikiran perlu mensyaratkan adanya kebebasan untuk bertindak secara etis, dan pada akhirnya kehidupan etis mensyaratkan keabadian dan ini berarti Tuhan (summun bonum). Kant berusaha menunjukkan bahwa pandangan ganda pada kenyataan ini tidak bertentangan dalam dirinya. Menurutnya pendekatan ilmiah hanya memberikan penampakan, sedangkan pendekatan praktis mendekatkan pada realitas.

Rudolph Bultmann memodifikasi pandangan Kant untuk membedakan perspektif teoritis dan eksistensial. Dari perspektif pertama Tuhan tidak mendapatkan tempat untuk berkarya di dunia; akan tetapi dari perspektif eksistensial, untuk setiap orang yang beriman setiap peristiwa bisa dianggap sebagai karya Tuhan. Bagaimana penyebaban Ilahi dan alamiah berlangsung, tidak perlu dijelaskan. Dari satu perspektif, peristiwa-peristiwa itu sepenuhnya dijelaskan dalam kerangka sebab-sebab alamiah, sedangkan dari perspektif lain ini dijelaskan sebagai karya Tuhan. ${ }^{24}$

Sebagian besarkarenajasa filsuf Austria, LudwigWittgenstein, dualisme perspektif model Kant ini dibawa ke Inggris dan dari sana mempengaruhi filsafat agama di Amerika. Secara meluas paling tidak Wittgenstein dianggap sebagai orang yang mendukung pandangan yang mengatakan bahwa ilmu pengetahuan dan agama adalah dua permainan bahasa yang masing-masing sama sekali otonom. Dualisme ini sebagai reaksi antimetafisik dalam lingkungan pemakai filsafat bahasa Inggris. Pendekatan ini menolak perlunya kerangka metafisik untuk menyelaraskan klaim-klaim yang muncul dari ilmu pengetahuan dan agama. ${ }^{25}$ Gagasan untuk memberikan bukti atau Argumenasi tentang eksistensi Tuhan, atau bahkan hanya dengan menunjukkan bahwa hal itu cocok dengan anggapan-anggapan

${ }^{24}$ Baca Rudolf Bultmann, Jesus Christ and mythology, (New York: Charles Schribner's Sons, 1958).

${ }^{25}$ Lihat Ian Barbour, Issues in Science and Religion, (Englwood Cliffs, N.J: Printice Hall, 1960). 
dasar dari penemuan ilmu pengetahuan modern menjadi bahan tertawaan.

Usaha untuk melindungi rasa percaya pada Tuhan dengan mengasingkannya dari pandangan dunia yang dihubungkan dengan pandangan dunia modern tidak berhasil. Selama pandangan dunia modern itu diterima, ada tekanan untuk mendefinisikan ulang Tuhan atau menghentikan saja pembicaraan tentang Tuhan.

Walaupun begitu, pikiran manusia pada akhirnya menuntut pandangan terpadu yang secara utuh dan integral bisa memberikan gambaran. Sekarang secara positif kini muncul suatu pandangan dunia postmodern yang didukung oleh para ilmuwan yang menaruh minat pada bentuk-bentuk kemasyarakatan dan kehidupan spiritual. Dalam konteks baru ini, teologi postmodern memuat teisme spiritual yang berbeda dengan pandangan teisme sebelumnya. Secara epistemologis teologi ini berlandaskan pada pengakuan akan adanya persepsi non-inderawi dalam memahami kenyataan di luar diri subyek pengamat. Dimana gagasan pokoknya adalah adanya derajat nilai intrinsik, keterarahan nilai intrinsik, keterarahan evolusi pada organisme dengan nilai intrinsik yang lebih tinggi, serta suatu perspektif Ilahi yang menghargai nilai intrinsik pada alam.

Dalam pandangan dunia postmodern ini terkandung empat macam kritik terhadap anggapan dasar modernitas dengan menggunakan argumen pragmatis, filosofis, historis, dan ilmiah.

Argumen pragmatis secara implisit mengkritik konsekwensikonsekwensi relativistik dan nihilistik dalam pandangan dunia modern. Ketika dunia modern memandung dunia sebagai tidak memiliki semua nilai obyektif dan makna. Manusia yang hidup dan dibesarkan di dunia ini dan menjadi bagIan integral darinya, tidak bisa hidup selaras dengan pandangan dunia yang seluruhnya relativistik dan nihilistik. Oleh karena itu harus ada praduga yang menolak pandangan dunia modern itu. ${ }^{26}$

Argumen historis menyangkal adanya anggapan bahwa bangkitnya ilmu pengetahuan modern mensyaratkan pandangan mekanistik terhadap alam, tetapi telaah lebih dalam menunjukkan

${ }^{26}$ David Ray Griffin, Tuhan dan Agama dalam Postmodern, terj. Gunawan Admiranto, (Yogyakarta: Kanisius, 2005), h. 92. 
bahwa perkembangan yang dihubungkan dengan kebangkitan ilmu pengetahuan modern berlangsung dalam konteks pandangan dunia yang bersifat holistik, neo-Platonik, dan Hermetik. Pandangan seperti ini adalah sebenarnya pandangan dunia yang non mekanistik, sehingga pandangan dunia yang mekanistik kemudian diterima lebih karena alasan-alasan teologis dan sosiologis daripada karena alasan-alasan empiris atau ilmiah. ${ }^{27}$

Argumen ilmiah merupakan perkembangan yang berlangsung dalam ilmu alam yang memberikan bukti empiris untuk membuktikan kesalahan pandangan mekanistik dengan gagasan tentang materi dasarnya. ${ }^{28}$

Sedangkan argumen filosofis menjelaskan bahwa dualisme jiwa dan tubuh, spiritual dan material, yang awalnya digagas oleh Descartes di awal modernisme akhirnya berujung pada epistemologi dan ontologi yang materialistik belaka, tanpa jiwa dan tanpa dimensi spiritual. Atau kalaupun dimensi jiwa dan spiritual dianggap masih ada, maka itu dianggap sebagai keyakinan pribadi, wilayah privat. Akibatnya dalam dunia modern terjadi dualisme yang tak terjembatani antara wilayah publik dan wilayah privat; antara wilayah material fisik dan wilayah spiritual nonfisik; antara sains dan agama; akhirnya antara dunia material dan dunia spiritual. ${ }^{29}$

Argumen filosofis menyerang landasan dualisme CartessianNewtonian yang menyatakan bahwa satuan-satuan dasar dunia (yang menurut fisika modern disebut partikel elementer) memberikan penjelasan bahwa materi secara Cartessian-Newtonian tidakmemiliki kedalaman, tidak memiliki persepsi, tidak memiliki pengalaman dalam bentuk apapun, dan tidak memilki nilai-nilai spiritual, sehingga orang akan menjadi dualis atau materialis sepenuhnya, seperti yang dikatakan oleh kaum materialis bagaimana caranya menjelaskan alam dan badan yang meteri bisa berhubungan dengan Tuhan yang non materi. ${ }^{30}$

${ }^{27}$ Lihat Paul Feyerabend, Against Method: Outline of Anarchistic Theory of Knowledge, (London: Verso, 1978).

${ }^{28}$ Penjelasan lengkap tentang itu dapat dilihat dalam Greg Soetomo, Sains \& Problem Ketuhanan, (Jogjakarta: Kanisius, 1995).

${ }^{29}$ Lihat David Ray Griffin, Tuhan dan Agama Dalam Dunia Postmodern, (Jogjakarta: Kanisius, 2005), h. 92-95.

${ }^{30}$ Argumen filosofis yang menentang materialisme lebih lanjut dapat 


\section{Etika Teologi Postmodern: Jalan Keluar dari Formalisme Teologis}

Istilah postmodernitas hakikatnya mengacu pada suatu era di mana kepercayaan pada modernitas mulai memudar. Misalnya mulai hilangnya kepercayaan kepada masa modern bahwa ilmu pengetahuan dapat menciptakan kemakmuran, bahwa modernitas dapat menghilangkan kemiskinan dan ketidakadilan; bahwa ilmu pengetahuan dapat membawa kemajuan bagi kemanusiaan. Hilangnya kepercayaan itu disebabkan oleh kenyataan bahwa ilmu pengetahuandanteknologimemang dapatmembantumanusiauntuk memenuhi keinginannya, akan tetapi juga di sisi lain menimbulkan banyak masalah dan penderitaan, seperti kerusakan lingkungan, peperangan, dan ancaman nuklir. Peristiwa ini membuktikan bahwa modernitas bukan saja tidak dapat menghilangkan kemiskinan dan ketidakadilan, akan tetapi sekaligus membuktikan bahwa modernitas membawa dampak negatif. Modernitas yang dicirikan dengan manusia yang rasional dalam banyak hal ternyata bertindak tidak rasional.

Bila pandangan dunia modern berciri anti spiritualitas, maka kini muncul pandangan postmodern yang kaya dengan dimensi spiritualitas, tapi kemampuannya secara intrinsik: bahwa gagasannya harus teruji dalam konsistensi-diri serta kesesuaiannya dengan seluruh realitas yang ada dalam pengalaman. Syarat formal inilah yang membedakan pandangan dunia postmodern dengan kebanyakan pandangan pra modern dan modern. ${ }^{31}$

Dunia postmodern memerlukan pandangan dunia yang lebih holistik. Diri manusia dengan segala kualitas personalnya, sekarang dilihat lagi sebagai bagian dari dunia ciptaan dan sekaligus pula dilihat lagi sebagai mahkota penciptaan, sebagai contoh utama di planet ini dari kualitas-kualitas yang terkandung dalam semua makhluk. Pandangan ganda ini memberikan landasan untuk menolak antroposentrisme, yang menganggap makhluk lain tidak

dilihat pada bagian pendahuluan dari buku The Reenchantment of Science: Postmodern Proposals, David Gray (ed.), (Albany: State University of New York Press, 1988).

${ }^{31}$ David Gray, (ed.), God and Religion in the Post Modern World, diterjemahkan oleh Gunawan Admiranto, Tuhan dan Agama dalam Dunia Postmodern, (Yogjakarta: Kanisius, 2005), h. 43. 
memiliki arti penting apapun kecuali kegunaannya bagi manusia, namun sekaligus berpendirian bahwa manusia secara intrinsik lebih penting daripada makhluk-makhluk penghuni bumi lainnya.

Dalam posisi ini terkandung panerergisme, yaitu gagasan yang menyatakan bahwa dunia seluruhnya tersusun dari benda-benda yang mengandung energi. Gagasan ini diterima secara luas sejak masa Einstein, yang rumusnya menyatakan bahwa ada kesetaraan antara massa dengan energi. Dengan mengikuti pemikiran Whitehead, energi diperluas menjadi kreativitas, hingga mencakup sel-sel hidup, tubuh manusia dan pikiran atau jiwa. Tidak terdapat dualisme antara pikiran (yang aktif) secara internal dan badan yang pasif, seperti pada masa modern. Pikiran dan segala sesuatu yang menyusun badan kita, kedua-duanya memiliki energi atau kreativitas, bahkan seluruh being di alam ini punya energi, kreativitas walau dalam komposisi yang tidak sama sebagai pendapatnya: This creative principle is everywhere in animate, and so-called in animate matter, in the water, earth, human hearts. ${ }^{32}$

Dalam hubungannya dengan bidang teologi, pandangan postmodern tentang konsep penciptaan seperti yang digagas oleh Whitehead adalah dunia diciptakan oleh Tuhan yang berpribadi, walaupun begitu Tuhan yang berpribadi di sini bukanlah Tuhan yang menciptakan dunia seisinya dari kehampaan mutlak (creatio ex nihilo). Tuhan dalam dunia postmodern menciptakan dunia tidak dari kehampaan mutlak, melainkan dengan memberikan keteraturan terhadap alam yang tak teratur ini (chaos) yang terdiri dari peristiwa-peristiwa yang energetik. Tuhan tidak menciptakan secara sepihak melainkan memberi inspirasi kepada makhluk untuk terus berkreasi sendiri dengan menanamkan suatu perasaan penting yang terus berkembang secara bertahap dalam diri mereka, sehingga kenyataan ada banyak kejahatan dalam dunia ini tidaklah bertentangan dengan realitas dan kebaikan sang Ilahi.

Di samping diakuinya kualitas pribadi manusia menjadi suatu kualitas tertinggi di seluruh tatanan alam semesta, karena dianggap sebagai imago dei (citra Ilahi) sebagai yang dipahami pada abad pertengahan, tetapi tetap memandang alam semesta memiliki makna dan nilai, sehingga pandangannya tidak terjatuh pada

${ }^{32}$ Whitehead, Process and Reality, (New York: The Free Press, 1979), h. 350. 
antroposentrisme. Walaupun manusia dianggap menduduki tempat yang istimewa dalam menduduki tata surya alam ini dan dianggap sebagai mahkota penciptaan di muka bumi, dan diciptakan dengan citra Tuhan, tapi tidak menganggap ketakbermaknaan alam semesta.

Pemikiran postmodern berusaha mempromosikan penghormatan mendalam sebagaimana yang diberikan oleh kaum ekologis egalitarian terhadap keseimbangan dalam alam pada tiga pokok berikut: pertama, setiap mahluk memiliki nilai intrinsik, nilai makna dalam dirinya. Oleh sebab itu, bentuk-bentuk individu yang lebih tinggi dengan pengalaman yang lebih kaya, secara definisi memiliki nilai intrinsik yang lebih tinggi; kedua, setiap individu juga memiliki nilai ekologis, baik positif maupun negatif terhadap ekosistem. Secara umum, semakin sedikit nilai intrinsik yang dimiliki individu, semakin positif nilai ekologis spesiesnya terhadap ekosistem; dan ketiga dalam memikirkan nilai keseluruhan setiap makhluk, kita tidak boleh hanya mempertimbangkan nilai dalam dirinya dan nilainya bagi makhluk fana lainnya, tetapi nilainya bagi pengalaman Ilahi. Pengalaman yang sangat menyeluruh ini bisa dianggap menghargai semua nilai ekologis yang positif selama mereka bisa merealisasikan nilai-nilai intrinsik demi mereka sendiri. Kita bisa menganggap bahwa kualitas pengalaman manusia yang khas akan menyumbangkan bentuk khusus pemenuhan pengalaman Ilahi.

Dalam konteks baru ini, kedudukan dan hakikat teologi mengalami perubahan dan mendapatkan penafsiran baru, karena ada pembaruan minat terhadap spiritualitas religius sebagai landasan kehidupan individu maupun sosial. Namun, peranan tersebut tidak bisa dimainkan oleh teologi tradisional formalistik atau teologi liberal modern yang dianggap telah gagal menjawab tantangan zaman.

Usaha untuk mengembalikan kepercayaan kepada Tuhan dengan mempertahankan komitmen formal modernitas terhadap kebebasan, pengalaman, dan penalaran, hanya mungkin dilakukan berlandaskan pada pandangan dunia postmodern atau dengan mengembalikan spiritualitas pra modern. Nilai-nilai spiritualitas 
dan kebenaran-kebenaran pra modern digali kembali, sambil diletakkan dalam kerangka yang lebih luas.

Demikianlah teologi postmodern sangat mendukung dimensi spiritualitas yang merujuk pada pengalaman religius. Tokoh pemikir Barat yang menggagas pentingnya kembali menghidupkan dimensi spiritualitas lewat teologi proses adalah Alfred North Whitehead. Menurutnya, manusia lebih banyak mengalami daripada menganalisis, ia mengalami alam raya, sementara ia hanya mampu menganalisis sebagian kecil dari apa yang dialami dalam kesadarannya itu. Berkat pengalaman dan pengamatannya terhadap ketertiban alam semesta yang menakjubkan mengarahkan pemahamannya kepada kerangka menyeluruh tentang dekatnya Tuhan di tengah-tengah keteraturan tadi.

Teologi proses selanjutnya menuntut adanya keterpaduan antara emosionalitas spiritual dan kreativitas intelektual, sehingga proses penciptaan atau kreativitas hanya dimungkinkan lewat immanensi Ilahi. Ketertiban atau keteraturan sempurna akan tercapai melalui harmonisasi Ilahi, yaitu ketika Dia menjadi semua dalam semua. Hal ini merupakan wujud penyatuan antara pengalaman emosional dan justifikasi konseptual, sehingga didapatkan suatu pemahaman akan adanya kesatuan realitas dengan berbagai tingkatan dimensionalitasnya.

Dalam khazanah pemikiran Islam, tokoh Ibn al-'Arabî dapat disejajarkan dengan Whitehead dalam mewacanakan relasi ontologis antara Tuhan dan alam semesta. Adalah Ibn al-'Arabî menyatakan bahwa Tuhan sebagai wujud mutlak baru dapat dikenal ketika Dia menampakkan dirinya di alam empiris, sehingga realitas tunggal itu menjadi dua aspek, yakni al- $\underline{H} a q q$, bila dipandang sebagai esensi dari semua fenomena; dan kedua al-Khalq, yakni bila dipandang sebagai fenomena yang memanifestasikan esensi itu. Al-Haqq dan al-khalq adalah realitas dan penampilan. Ibn al-'Arabî menganggap alam sebagai sesuatu yang hidup, yang mendengar, yang melihat, yang mengetahui, yang berkehendak, dan yang berkuasa ${ }^{33}$.

Kesadaran wahdat al-wujūd dalam pandangan mistik Ibn al-Arabī inilah yang kemudian menjadi kesadaran kosmik yang

${ }^{33}$ Lihat Ibn al-'Arabî, al-Futūhāt al-Makkiyyah, (Kairo: Dār al-Kutub al'Arabiyyah al-Kubrā, 1329/1911; Beirut: Dāru al- Fikr, t.t), jilid II, h. 438. 
disebut oleh Henry Corbin sebagai sympatheia. ${ }^{34}$. Sympatheia adalah sejenis sense of other atau sense of relation, yaitu kesadaran sebagai relasi dengan yang lain yang menumbuhkan perasaan persahabatan yang diarahkan atau ditujukan kepada sesuatu di luar diri, baik seiman atau tidak, bahkan relasi dengan alam. Kesadaran ketunggalan mistik (unio mystica) merupakan kesadaran ketunggalan sympatheia (unio sympatheIa) yang tumbuh melalui kekuatan cinta Ilahi yang dimanifestasikan dalam segenap alam raya beserta isinya. Dengan penjelasan ini alam semesta dalam konsep Ibn al-'Arabî diumpamakan sebagai cermin tempat Tuhan melihat dirinya dan perwujudan cintanya.

\section{E. Penutup}

Klaim kebenaran teologi beserta landasan ideologi dan ajaran moral yang dibawanya mempunyai peran yang cukup besar dalam menuntukan tindakan seseorang. Abad pertengahan telah membuktikan sejarah hitam teologi yang telah mendehumanisasi manusia lewat institusi agama. Agama kehilangan dimensi religiositas dan spiritualitasnya yang akhirnya berujung pada munculnya materialisme ilmiah dan nihilisme moral pada masa modern. Dalam pada itu, materialisme ilmiah dan nihilisme moral telah menyebabkan munculnya prinsip "survival of the fittest" sebagai satu-satunya landasarn etis dalam setiap tindakan manusia, sehingga terjadilah tribalisme, nuklirisme, dan prinsip yang kuat yang menang.

Klaim kebenaran teologi abad pertengahan dan modern harus segera digantikan dengan klaim kebenaran teologi postmodern yang bercirikan holistik spiritualistik, yang menghargai segala being karena dianggap sebagai refresentasi cinta Tuhan yang memilki energi, kreativitas, dan hidup dalam dunia yang saling berketergantungan. []

${ }^{34}$ Henry Corbin, Creative Imagination in the Sufism of Ibn Arabi ( New York: Princeton University Press, 1981), h. 107-112. 


\section{Daftar Pustaka}

Ahern, M.B., The Problem of Evil, Routledge \& Kegan Paul: London, 1971.

Amstrong, Karen, The Battle for God, New York: Alfred A. Knopi, 2001.

al-'Arabī Ibn, al-Futūhāât al-Makkiyah, Jilid II, Kairo: Dāru al-Kutub al-'Arabiyah al-Kubrâ, Beirut: Dâr al- Fikr, 1329.

Barbour, Ian, Issues in Science and Religion, Englewood Cliffs, N.J : Printice Hall, 1960.

Baumer, Franklin L., Religion and the Rise of Scepticism, New York: Harcout, Brace \& World, 1980.

Bermen, M., The Reeinchanment of the World, New York: Bantam Books, 1984.

Bultman, Rudolf, Jesus Christ and mythology, New York: Charles Schribner's Sons, 1958.

Brandon, S.G.E, M.A, DD., (ed.) A Dictionary of Comparative Religion, New York: Charles Scribner's Sons, 1970.

Coplestone, Frederick A History of Philosophy, volume I. Medieval Philosophy, from Agustin To Dons Scotus, New York: Doubeday, 1993.

, A History of Philosophy, volume II. Medieval Philosophy, from Agustin To Dons Scotus, New York: Doubeday, 1993.

Corbin, Henry, Creative Imagination in the Sufism of Ibn Arabi, New York: Princeton University Press, 1981.

Feyerabend, Paul, Against Method: Outline of Anarchistic Theory of Knowledge, London: Verso, 1978.

From, Erich, Religion and Psychoanalysis, New York: Vail-Ballou Press, Ins, 1997.

Griffin, David Ray, God and Religion in the Post Modern World, terj. Gunawan Admiranto, Tuhan dan Agama dalam Dunia Postmodern, Yogyakarta: Kanisius, 2005.

Habermas, Jürgen, The Philosophical Discourse of Modernity, Massachussetts: The MIT Press Cambridge, 1992. 
Hanafi, Hassan, Mina l-Aqidah ila Tsawrah, Vol 1, Kairo: Maktabah Madbouli, 1988.

Hidayat, Komaruddin, Tragedi Raja Midas: Moralitas Agama dan Krisis Modernisme, Jakarta, Paramadina, 1988.

Klareen, Eugene, Religious Origins of Modern Science: Belief in Creation in Seventeenth-Century Thought, Grand Rapids, MIch.: WillIam B. Erdsman, 1977.

Kimball, Charless, Kala Agama Menjadi Bencana, terjemahan Nurhadi, Bandung: Mizan, 2003.

Langford, JeromeJ., Galileo, Science, and the Church, Ann Arbour : University of Michigan Press, 1971.

Nasr, Sayyed Hussein, Knowledge and the Sacred, New York: State University of New York Press, 1989.

Soetomo, Greg, Sains \& Problem Ketuhanan, Yogyakarta: Kanisius, 1995.

Steenbrink, Karel A., Perkembangan Teologi dalam Dunia Kristen Modern, Yogyakarta: IAIN Sunan Kalijaga Press, 2005.

Stewart, David, Exploring the Philosophy of Religion, Englewood Cliffs, N.J: Prentice-Hall, 1980.

Suseno, Frans Magnis, Menalar Tuhan, Yogyakarta: Kanisius, 2006.

Syahrastani, Kitab al-Milal wa Nihāl, ed Muhammad ibn Fathullah Badran, Kairo: tp, tt.

Whitehead, Alfred North, Process and Reality, New York: The Free Press, 1979.

__- Science and the modern World, New York: Mentor Book, 1954. 
Naupal

halaman ini bukan sengaja dikosongkan 